ORIGINAL ARTICLE / ARTIGO ORIGINAL

\title{
Trends in prevalence of overweight and obesity in adults in 26 Brazilian state capitals and the Federal District from 2006 to 2012
}

\author{
Evolução anual da prevalência de excesso de peso e obesidade em adultos nas \\ capitais dos 26 estados brasileiros e no Distrito Federal entre 2006 e 2012
}

\author{
Deborah Carvalho Malta',II, Silvania Caribé Andrade', Rafael Moreira Claro III,IV, \\ Regina Tomie Ivata Bernal'v, Carlos Augusto Monteirolv
}

\begin{abstract}
Objective: To describe the annual evolution of the prevalence of overweight and obesity in the adult population of the 26 Brazilian state capitals and the Federal District from 2006 to 2012. Methods: Annual interviews (around 54,000 per year) from VIGITEL (Surveillance System of Risk and Protective Factors for Chronic Non-Communicable Diseases through Telephone Interviews) were used. Self-reported weight and height were used to estimate body mass index and nutritional status. Prevalence estimates of overweight and obesity are presented according to gender, age and schooling and to each city. Linear regression model was used to evaluate the time trend of prevalence. Results: Prevalence of overweight in adults in the 27 cities monitored by VIGITEL increased from $43.2 \%$ (2006) to $51.0 \%$ (2012), with an annual increase rate of $1.37 \%$. Prevalence of obesity increased from $11.6 \%$ to $17.4 \%$, with an annual increase rate of $0.89 \%$. The study showed a statistically significant increase in the prevalence of overweight in all cities, and for both genders, all age groups and all levels of schooling. Similar trends were also verified for obesity. Conclusions: If the trends verified from 2006 to 2012 are maintained, in ten years, around two-thirds of the adults in Brazilian state capitals will be overweight, and a quarter will be obese. This perspective requests urgent response from government and intersectoral actions to combat the obesogenic environment.
\end{abstract}

Keywords: Overweight. Obesity. Telephone-Based Surveillance System. Chronic disease. Trends. Brazil.

'Department of Non-Communicable Diseases Surveillance and Health Promotion, Secretariat of Health Surveillance, Ministry of Health - Brasilia (DF), Brasil.

"Departamento Materno Infantil e de Saúde Pública, Escola de Enfermagem, Universidade Federal de Minas Gerais Belo Horizonte (MG), Brasil.

"'Departamento de Nutrição, Escola de Enfermagem, Universidade Federal de Minas Gerais - Belo Horizonte (MG), Brasil.

"Núcleo de Pesquisas Epidemiológicas em Nutrição e Saúde, Faculdade de Saúde Pública, Universidade de São Paulo São Paulo (SP), Brasil.

Corresponding author: Deborah Carvalho Malta. Departamento de Vigilância de Doenças e Agravos Não Transmissíveis e Promoção da Saúde, Secretaria de Vigilância em Saúde, Ministério da Saúde. SAF Sul, Trecho 02, Lotes 05 e 06 , Bloco F, Torre I, Edifício Premium, Térreo, Sala 16, CEP: 70070-600, Brasília, DF, Brazil. E-mail: deborah.malta@saude.gov.br

Conflict of interests: nothing to declare - Financing source: none. 
RESUMO: Objetivo: Descrever a evolução anual da prevalência de excesso de peso e de obesidade na população adulta das capitais dos 26 estados brasileiros e no Distrito Federal entre 2006 e 2012. Métodos: A fonte de dados são entrevistas anuais (cerca de 54 mil ao ano) do sistema VIGITEL (Vigilância de Fatores de Risco e Proteção para Doenças Crônicas por Inquérito Telefônico). Informações autorreferidas de peso e altura foram usadas para calcular o Índice da Massa Corporal e classificar o estado nutricional. Estimativas da prevalência de excesso de peso e obesidade são apresentadas segundo sexo, idade e escolaridade e, também, para cada cidade. Modelos de regressão linear avaliaram a significância estatística da variação temporal nas prevalências. Resultados: A prevalência de excesso de peso na população adulta das 27 cidades monitoradas pelo VIGITEL aumentou de 43,2\% (2006) para 51,0\% (2012), sendo de 1,37\% o incremento anual médio calculado para o período. A prevalência da obesidade aumentou de $11,6 \%$ para $17,4 \%$, com incremento anual de $0,89 \%$. Aumento estatisticamente significativo na prevalência do excesso de peso foi observado em todas as cidades, nos dois sexos, em todas as faixas etárias e em todos os níveis de escolaridade. Evolução semelhante foi observada para a obesidade. Conclusão: Mantidas as tendências observadas no período entre 2006 e 2012, em dez anos, cerca de dois terços dos adultos nas capitais dos estados brasileiros terão excesso de peso, e cerca de um quarto será obeso, o que demanda urgente resposta do poder público e articulações intersetoriais que tornem o ambiente menos obesogênico.

Palavras-chave: Sobrepeso. Obesidade. Sistema de Vigilância por Inquérito Telefônico. Doença crônica. Tendências. Brasil.

\section{INTRODUCTION}

Non-Communicable Diseases (NCD), including cardiovascular diseases, cancer, diabetes mellitus and chronic respiratory diseases, are considered an important public health problem ${ }^{1}$. The NCD are associated with several risk factors, especially overweight, unhealthy diet, physical inactivity, excessive consumption of alcoholic beverages and smoking ${ }^{1-3}$. Estimates from the World Health Organization (WHO) indicate that, in 2010, the NCD were responsible for $63 \%$ of deaths worldwide ${ }^{1}$.

Excess of weight (including the conditions of overweight and obesity) is the sixth most important risk factor for the global burden of diseases ${ }^{2,3}$ as for its association with several NCD, including cardiovascular diseases, such as hypertension and stroke, diabetes, colon, rectum and breast cancer, cirrhosis, gout, osteoarthritis and sleep apnea ${ }^{1,2,4-7}$. It is estimated that, currently, one billion adults are overweight worldwide and about 475 million of them are obese ${ }^{5}$, protruding even more impressive numbers for the next decade ${ }^{5,6}$. Estimates for 2020 indicate about five million deaths attributed to overweight ${ }^{1,2}$.

Home-based nutritional surveys, repeated at various intervals of time, have shown systematic increases in the prevalence of overweight and obesity in many countries around the world ${ }^{1,5,8,9}$ and, also, in Brazil ${ }^{10}$. 
Since 2006, Brazil has a national system for monitoring risk factors through telephone interviews called Protective and Risk Factors for Chronic Diseases by Telephone Survey - VIGITEL. This system provides annual estimates on the prevalence of overweight and obesity, and several other risk factors for chronic diseases in the adult population of all the capitals of Brazil's 26 states and the Federal District ${ }^{11}$.

This study aims at describing the annual evolution of the prevalence of overweight and obesity in the adult population of the capitals of Brazil's 26 states and the Federal District from 2006 to 2012.

\section{METHODS}

All data analyzed in this study come from the VIGITEL system. This system interviews approximately 54 thousand individuals aged 18 years old or older every year, being about two thousand of them in each of the capitals of the 26 Brazilian states and the Federal District. The sampling process of the system is done by cities and in two steps, involving the drawing of random samples of telephone lines and the random selection of one resident aged 18 years old or older by their telephone line. Details about the sampling process of the VIGITEL are provided in the annual reports of the technical system ${ }^{11}$.

The VIGITEL data analyzed in this study include weight and height reported by the respondents as well as their age, gender and level of schooling/education. In 2012, the VIGITEL performed the imputation of the missing data on weight and height. Initially the variables associated with lack of response, as well as the age, gender, education and race/color were identified. The resulting model of this process allows the creation of groups of respondents and non-respondents with similar characteristics to the predictors of the condition of non-response. Finally, in every capital, it was selected, randomly, within each group, a person with known information to "donate" their weight or height values for the non-respondent belonging to the same group. Methodological details may be found in another publication ${ }^{11}$.

All estimates of the VIGITEL are weighted, so that they are representative of the total adult population of each city. The weight initially assigned to each individual respondent to the VIGITEL is the multiplication of two factors: the inverse of the number of telephone lines in the household and the number of adults in the household of the interviewee. This weight, which makes significant the estimates of the adult population served by home phone lines, is then multiplied by a second weight, called post-stratification weight. This second weight aims to equalize the sociodemographic composition of the population served by household telephone lines to the sociodemographic composition of the total adult population of each city in the year of the survey ${ }^{11,12}$. The calculation of the post-stratification weight is done by the rake method ${ }^{11,12}$ and it considers the variables of gender, age and educational level. This method uses iterative procedures which take into account successive comparisons between the estimates of the distribution of each sociodemographic variable in the sample 
population served by telephone and the same estimates on the city's total population, the latter obtained from projections based on census data. Details on the process for weighting estimates from VIGITEL, as well as other details of the methodology are provided in the annual publication of its results ${ }^{11}$.

This study analyzed data on the prevalence of overweight and obesity in adults. It was considered to be overweight the individuals with Body Mass Index (BMI) $\geq 25 \mathrm{~kg} / \mathrm{m}^{2}$, and as obese those with BMI $\geq 30 \mathrm{~kg} / \mathrm{m}^{2}$, according to data from the World Health Organization ${ }^{4}$. The BMI corresponds to the division of the weight in kilograms by the square of the height in meters. VIGITEL obtains information on weight and height with the questions: "Do you know your weight (even approximately)?" and "Do you know your height?".

Trend in the prevalence of overweight and obesity was estimated for the whole population of the 27 cities studied, for strata of this population defined by gender, age group ( 18 to 24,25 to 34,35 to 44,45 to 54,55 to 64 and 65 years old and older), education (0 to 8 years, 9 to 11 and 12 or more years of schooling), for each city individually and for groups of cities belonging to the same macro-region (North, Northeast, Midwest, South and Southeast).

In order to identify the existence of a linear trend in the temporal variation of the evolution of the indicators, were used linear regression models which consider as a dependent variable the prevalence of overweight or obesity, and each year of the study was used as explanatory variable ${ }^{13}$. The value of the slope of these models expresses the average annual change (increase or decrease) in the prevalence of overweight or obesity. It was considered the existence of a significant linear trend when the slope of the model was shown to be different from zero for a p-value lower than 0.05 . Stata statistical software was used for data analysis ${ }^{14}$. The data collection done by the VIGITEL was approved by the National Ethics Committee on Human Research.

\section{RESULTS}

\section{PREVALENCE OF OVERWEIGHT}

The prevalence of excessive weight in the adult population living in the capitals of Brazil's 26 states and in the Federal District increased from $43.2 \%$ in 2006 to $51.0 \%$ in 2012, with a $1.37 \%$ average annual increase calculated for the period. The prevalence of overweight increased significantly in men and women, in all age groups and in all levels of schooling. The average annual increase in prevalence was higher for women, for younger age groups and for the strata with higher education. This trend eventually narrowed the sociodemographic differences in the distribution of excess weight, because, at the beginning of the period, the prevalence of overweight was higher among men in the oldest age groups and with lower levels of education (Table 1). 
Missing-data imputation of weight and height in 2012 for the total of the capitals altered the prevalence of $51.4 \%$ without imputation to $51 \%$ with imputation (data not shown).

Prevalence of overweight increased significantly in all 27 cities covered by the VIGITEL with an average annual growth ranging from just over one percentage point in Belo Horizonte $(+1.21 \%)$ to just over two percentage points in Maceio $(+2.18 \%)$. The increases tended to be higher in cities in the North, Northeast and Midwest regions than in cities in the South and Southeast regions, which, in this case also contributed to homogenize the distribution of the prevalence of overweight in Brazil (Table 2).

\section{PREVALENCE OF OBESITY}

In the period from 2006 to 2012, the prevalence of obesity in the adult population of the 27 cities covered by the VIGITEL system increased from $11.6 \%$ to $17.4 \%$, representing an average increase of $0.89 \%$ per year. Significant increases were observed for men and women, in all age groups (with the exception of the elderly, where the increase was not constant throughout the period) and at all levels of schooling. The increase in the prevalence of obesity for women was slightly higher, in subjects between 25 and 44 years of age and lower educational levels. According to these trends, in 2012, obesity became more frequent in women than in men (prevalence in both gender were similar in 2006) and have increased

Table 1. Estimates of the prevalence (\%) of overweight* in the adult population ( $\geq 18$ years of age) residing in the capitals of Brazil's 26 states and the Federal District by gender, age and educational level. VIGITEL, 2006 - 2012.

\begin{tabular}{|c|c|c|c|c|c|c|c|c|}
\hline Variable & 2006 & 2007 & 2008 & 2009 & 2010 & 2011 & $2012^{* *}$ & $\begin{array}{c}\text { Annual average } \\
\text { variation in the period }{ }^{\delta}\end{array}$ \\
\hline \multicolumn{9}{|l|}{ Gender } \\
\hline Male & 47.9 & 48.9 & 50.3 & 50.5 & 53.2 & 53.8 & 54.5 & 1.16 \\
\hline Female & 38.8 & 38.1 & 40 & 42.3 & 44.3 & 44.7 & 48.1 & 1.62 \\
\hline \multicolumn{9}{|c|}{ Age range (years) } \\
\hline 18 to 24 & 20.9 & 20.4 & 22.9 & 25.7 & 27 & 25.5 & 28.9 & 1.37 \\
\hline 25 to 34 & 38.2 & 39.9 & 41.1 & 41.6 & 44.3 & 45.9 & 47.7 & 1.56 \\
\hline 35 to 44 & 49.3 & 48.6 & 49.6 & 51.2 & 52.3 & 55.1 & 55.9 & 1.27 \\
\hline 45 to 54 & 55.2 & 55.5 & 55.5 & 55.1 & 58.4 & 58.2 & 60.8 & 0.90 \\
\hline 55 to 64 & 57.4 & 57.9 & 59.2 & 60.0 & 61.8 & 60.5 & 60.3 & 0.59 \\
\hline 65 and more & 53.4 & 50.4 & 53.9 & 55.4 & 58.6 & 55.5 & 58.5 & 1.08 \\
\hline \multicolumn{9}{|c|}{ Educational level (years of study) } \\
\hline 0 to 8 & 50.3 & 50.0 & 50.6 & 53.0 & 55.6 & 55.0 & 57.3 & 1.29 \\
\hline 9 to 11 & 38.2 & 37.5 & 40.9 & 42.8 & 44.7 & 46.3 & 46.7 & 1.68 \\
\hline 12 and more & 37.4 & 40.4 & 41.0 & 40.8 & 43.9 & 44.8 & 48.4 & 1.60 \\
\hline Total & 43.2 & 43.4 & 45.0 & 46.3 & 48.6 & 49.1 & 51.0 & 1.37 \\
\hline
\end{tabular}

*Self-reported data. Utilized: Body Mass Index $\geq 25 \mathrm{~kg} / \mathrm{m}^{2}$. ** Imputed Data. ${ }^{\star}$ Obtained by linear regression models and statistically significant for the whole population and for all strata considered. 
the relative excess of obesity in individuals with low education. The increasing trend of obesity with age was not modified in the period (Table 3 ).

The allocation of data on weight and height in 2012 for total capital altered the prevalence of obesity from $17.1 \%$ without imputation to $17.4 \%$ with imputation (data not shown).

Table 2. Estimates of the prevalence (\%) of overweight* among the adult population ( $\geq 18$ years old) in the cities covered by the VIGITEL system, $2006-2012$.

\begin{tabular}{|c|c|c|c|c|c|c|c|c|}
\hline Cities & 2006 & 2007 & 2008 & 2009 & 2010 & 2011 & $2012^{* *}$ & $\begin{array}{c}\text { Annual average } \\
\text { variation in the period }^{£}\end{array}$ \\
\hline Aracaju & 40.3 & 39.4 & 43.6 & 46.4 & 48 & 45.6 & 51.5 & 1.80 \\
\hline Belém & 40.9 & 42.4 & 46.8 & 44.0 & 46.6 & 47.7 & 50.4 & 1.39 \\
\hline Belo Horizonte & 37.7 & 41.4 & 42.6 & 44.0 & 44.3 & 45.6 & 48.1 & 1.48 \\
\hline Boa Vista & 42.0 & 42.4 & 45.1 & 49.3 & 47.8 & 49.8 & 47.5 & 1.21 \\
\hline Campo Grande & 43.3 & 45.6 & 46.4 & 49.0 & 52.3 & 51.0 & 56.3 & 1.99 \\
\hline Cuiabá & 45.1 & 48.5 & 48.5 & 48.2 & 50.4 & 51.9 & 51.8 & 1.03 \\
\hline Curitiba & 44.1 & 44.1 & 46.3 & 46.5 & 49.1 & 50.1 & 51.6 & 1.33 \\
\hline Florianópolis & 41.2 & 43.1 & 41.5 & 45.4 & 45.3 & 47.6 & 48.6 & 1.25 \\
\hline Fortaleza & 42.5 & 45.2 & 45.9 & 47.8 & 51.7 & 52.0 & 52.8 & 1.80 \\
\hline Goiânia & 38.3 & 39.0 & 42.7 & 44.4 & 44.6 & 46.4 & 49.4 & 1.79 \\
\hline João Pessoa & 42.0 & 45.0 & 45.9 & 44.1 & 46.6 & 49.6 & 50.9 & 1.31 \\
\hline Macapá & 42.4 & 43.5 & 49.1 & 46.1 & 49.0 & 52.3 & 51.7 & 1.62 \\
\hline Maceió & 39.9 & 41.7 & 44.5 & 44.0 & 47.7 & 51.9 & 52.4 & 2.18 \\
\hline Manaus & 44.1 & 44.7 & 44.0 & 47.3 & 50.9 & 52.1 & 52.0 & 1.62 \\
\hline Natal & 43.3 & 45.9 & 44.9 & 46.1 & 48.9 & 51.6 & 52.2 & 1.50 \\
\hline Palmas & 37.3 & 34.4 & 38.6 & 38.9 & 40.9 & 40.7 & 45.3 & 1.39 \\
\hline Porto Alegre & 48.9 & 44.7 & 48.6 & 46.9 & 51.5 & 54 & 54.1 & 1.33 \\
\hline Porto Velho & 41.5 & 44.8 & 44.5 & 50.2 & 50.9 & 49.8 & 52.4 & 1.75 \\
\hline Recife & 44.4 & 43.7 & 45.5 & 46.6 & 50.3 & 49.1 & 53.3 & 1.51 \\
\hline Rio Branco & 44.1 & 42.5 & 49.1 & 49.5 & 53.0 & 51.9 & 53.9 & 1.86 \\
\hline Rio de Janeiro & 48.1 & 47.0 & 45.0 & 49.7 & 52.7 & 51.4 & 52.4 & 1.05 \\
\hline Salvador & 39.7 & 40.6 & 42.2 & 45.5 & 42.8 & 45.5 & 47.3 & 1.86 \\
\hline São Luís & 34.7 & 36.6 & 39 & 39.4 & 41 & 41.2 & 45.3 & 1.54 \\
\hline São Paulo & 44.4 & 43.6 & 47 & 47.5 & 49.5 & 48.1 & 52.1 & 1.24 \\
\hline Teresina & 35.7 & 38.5 & 37.7 & 40.1 & 44.3 & 45.6 & 46.4 & 1.89 \\
\hline Vitória & 39.1 & 41.5 & 42.9 & 45.2 & 46.2 & 46.8 & 48.0 & 1.45 \\
\hline Federal Disctrict & 41.4 & 39.3 & 41.4 & 39.2 & 44.3 & 50.1 & 46.6 & 1.43 \\
\hline \multicolumn{9}{|c|}{ Cities in the region } \\
\hline North & 42.3 & 43.1 & 45.4 & 46.3 & 48.9 & 49.9 & 51.1 & 1.55 \\
\hline Northeast & 40.7 & 42.2 & 43.5 & 45.2 & 46.9 & 48.2 & 50.2 & 1.57 \\
\hline Midwest & 41.3 & 41.2 & 43.2 & 42.9 & 46.2 & 49.5 & 49.3 & 1.56 \\
\hline Southeast & 44.7 & 44.4 & 45.8 & 47.7 & 49.8 & 48.8 & 51.6 & 1.20 \\
\hline South & 45.7 & 44.2 & 46.6 & 46.5 & 49.6 & 51.3 & 52.2 & 1.31 \\
\hline
\end{tabular}

*Self-reported data. Utilized: Body Mass Index $\geq 25 \mathrm{~kg} / \mathrm{m}^{2}$. ** Imputed Data. ${ }^{\star}$ Obtained by linear regression models and statistically significant for all cities and strata. 
Prevalence of obesity increased significantly in all the cities covered by the VIGITEL except in Belém and in the Federal District, where the increases were not regular over the period. The average annual growth ranged from almost half a percentage point in Belém $(0.43 \%)$ to almost one and a half percentage point in Rio Branco $(+1.37 \%)$, without significant variations between the regions (Table 4).

\section{DISCUSSION}

Estimates presented in this study and calculated from annual data VIGITEL between 2006 and 2012 in the capital cities of 26 Brazilian states and the Federal District document the extent and intensity of the obesity epidemic in Brazil. Systematic increases in the proportion of overweight adults were observed in all the cities monitored, in both gender, at all ages and at all levels of schooling. A similar situation characterizes the evolution of the proportion of obese people.

The obesity epidemic is a global phenomenon and its causes are complex, including changes in the environment which result in an increased consumption of processed foods of high caloric density and in a decreased energy expenditure due to the low levels of physical activity of the population ${ }^{4,5}$.

Table 3. Estimates of the prevalence (\%) of obesity* in the adult population ( $\geq 18$ years) resident in the capitals of Brazil's 26 states and the Federal District by gender, age and educational level. VIGITEL, $2006-2012$.

\begin{tabular}{|c|c|c|c|c|c|c|c|c|}
\hline Variable & 2006 & 2007 & 2008 & 2009 & 2010 & 2011 & $2012^{* *}$ & $\begin{array}{c}\text { Annual average } \\
\text { variation in the period }\end{array}$ \\
\hline \multicolumn{9}{|l|}{ Gender } \\
\hline Male & 11.4 & 13.5 & 13.4 & 13.7 & 14.4 & 15.4 & 16.5 & 0.72 \\
\hline Female & 11.8 & 12.1 & 13.5 & 14.0 & 15.4 & 16.1 & 18.2 & 1.04 \\
\hline \multicolumn{9}{|c|}{ Age range (years) } \\
\hline 18 to 24 & 4.2 & 4.0 & 4.4 & 6.2 & 5.1 & 5.7 & 7.5 & 0.5 \\
\hline 25 to 34 & 10.0 & 10.9 & 11.1 & 11.3 & 12.3 & 13.5 & 15.1 & 0.78 \\
\hline 35 to 44 & 12.4 & 14.7 & 14.9 & 15.4 & 16.2 & 18.9 & 19.7 & 1.23 \\
\hline 45 to 54 & 16.0 & 19.1 & 18.3 & 17.3 & 21.4 & 21.1 & 22.6 & 0.96 \\
\hline 55 to 64 & 17.4 & 19.5 & 20.9 & 21.2 & 20.1 & 20.5 & 23.4 & 0.69 \\
\hline 65 and more & 16.0 & 13.3 & 17.4 & 17.0 & 19.4 & 17.6 & 19.0 & 0.70 \\
\hline \multicolumn{9}{|c|}{ Educational level (years of study) } \\
\hline 0 to 8 & 15.1 & 16.1 & 17.3 & 17.5 & 18.7 & 19.3 & 21.7 & 0.99 \\
\hline 9 to 11 & 9.2 & 10.8 & 11.0 & 12.0 & 13.1 & 14.3 & 15.2 & 0.97 \\
\hline 12 and more & 8.7 & 9.9 & 10.3 & 10.6 & 11.9 & 12.9 & 14.4 & 0.88 \\
\hline Total & 11.6 & 12.8 & 13.4 & 13.8 & 14.9 & 15.8 & 17.4 & 0.89 \\
\hline
\end{tabular}


National household surveys in Brazil in 2002 - 2003 and in 2008 - 2009 confirm the trend of the rapidly increasing prevalence of overweight and obesity in adults, and also in adolescents, being interesting to note that the national prevalence among adults observed in the survey conducted in 2008 - 2009 were close to the prevalence estimated by VIGITEL in the 27 cities monitored by the system ${ }^{10,15}$.

Table 4. Estimates of the prevalence (\%) of obesity in the adult population ( $\geq 18$ years) in the cities covered by VIGITEL system, 2006 - 2012.

\begin{tabular}{|c|c|c|c|c|c|c|c|c|}
\hline Cities & 2006 & 2007 & 2008 & 2009 & 2010 & 2011 & $2012^{* *}$ & $\begin{array}{c}\text { Annual average } \\
\text { variation in the period }\end{array}$ \\
\hline Aracaju & 13.0 & 11.0 & 13.9 & 15.4 & 15.2 & 15.2 & 18.0 & 0.88 \\
\hline Belém & 12.8 & 13.6 & 13.3 & 12.4 & 15.4 & 13.6 & 16.1 & 0.43 \\
\hline Belo Horizonte & 8.9 & 11.0 & 11.8 & 12.3 & 12.3 & 13.9 & 14.5 & 0.83 \\
\hline Boa Vista & 12.1 & 12.2 & 14.6 & 13.8 & 14.2 & 14.9 & 15.1 & 0.50 \\
\hline Campo Grande & 11.9 & 15.3 & 14.1 & 16.5 & 16.9 & 18.0 & 21.0 & 1.27 \\
\hline Cuiabá & 13.0 & 14.0 & 14.5 & 14.8 & 18.7 & 17.8 & 19.2 & 1.09 \\
\hline Curitiba & 12.6 & 13.3 & 13.8 & 12.9 & 17.0 & 15.6 & 16.3 & 0.67 \\
\hline Florianópolis & 10.1 & 11.3 & 11.4 & 13.0 & 14.3 & 15.0 & 15.7 & 0.97 \\
\hline Fortaleza & 12.0 & 13.7 & 15.4 & 15.5 & 16.7 & 18.3 & 18.8 & 1.10 \\
\hline Goiânia & 9.9 & 11.4 & 11.2 & 11.5 & 12.7 & 13.5 & 14.0 & 0.64 \\
\hline João Pessoa & 13.7 & 12.6 & 14.4 & 13.4 & 14.8 & 15.6 & 19.9 & 0.89 \\
\hline Macapá & 13.7 & 16.2 & 14.3 & 14.6 & 17.1 & 19.5 & 17.6 & 0.75 \\
\hline Maceió & 13.0 & 12.2 & 14.1 & 13 & 14.8 & 18.0 & 19.9 & 1.18 \\
\hline Manaus & 13.5 & 12.8 & 14.9 & 15.7 & 17.4 & 19.1 & 19.6 & 1.19 \\
\hline Natal & 13.1 & 13.1 & 12.5 & 13.8 & 15.9 & 15.6 & 21.2 & 1.17 \\
\hline Palmas & 9.3 & 8.7 & 10.4 & 9.5 & 13.3 & 13.0 & 15.7 & 1.09 \\
\hline Porto Alegre & 12.8 & 12.7 & 15.3 & 14.3 & 15.1 & 18.1 & 18.4 & 0.98 \\
\hline Porto Velho & 12.8 & 15.3 & 13.5 & 18.0 & 16.3 & 17.2 & 18.9 & 0.89 \\
\hline Recife & 12.3 & 11.8 & 13.8 & 13.5 & 17.5 & 15.5 & 17.7 & 0.98 \\
\hline Rio Branco & 12.5 & 13.0 & 14.6 & 15.6 & 17.3 & 17.6 & 21.3 & 1.37 \\
\hline Rio de Janeiro & 12.8 & 14.2 & 13.0 & 16.6 & 16.3 & 17.4 & 19.5 & 1.06 \\
\hline Salvador & 9.8 & 12.8 & 12.2 & 14 & 12.4 & 14.1 & 14.1 & 0.56 \\
\hline São Luís & 9.0 & 9.6 & 9.8 & 10.6 & 12.0 & 12.7 & 13.2 & 0.75 \\
\hline São Paulo & 11.5 & 13.2 & 14.4 & 13.7 & 14.9 & 15.3 & 17.8 & 0.84 \\
\hline Teresina & 9.5 & 11.1 & 10.8 & 12.0 & 13.1 & 12.7 & 15.0 & 0.79 \\
\hline Vitória & 9.7 & 12.0 & 11.0 & 12.0 & 14.3 & 14.0 & 15.5 & 0.88 \\
\hline Federal Disctrict & 10.7 & 10.3 & 12.2 & 9.4 & 10.7 & 14.4 & 14.3 & 0.63 \\
\hline \multicolumn{9}{|l|}{ Cities in the region } \\
\hline North & 12.9 & 13.3 & 14.0 & 14.4 & 16.3 & 16.7 & 18.0 & 0.87 \\
\hline Northeast & 11.4 & 12.3 & 13.2 & 13.8 & 14.7 & 15.5 & 17.1 & 0.89 \\
\hline Midwest & 10.9 & 11.7 & 12.5 & 11.5 & 13.0 & 15.0 & 15.7 & 0.77 \\
\hline Southeast & 11.5 & 13.2 & 13.6 & 14.4 & 15.0 & 15.8 & 17.9 & 0.92 \\
\hline South & 12.4 & 12.8 & 14.2 & 13.4 & 15.9 & 16.5 & 17.1 & 0.83 \\
\hline
\end{tabular}

*Self-reported data. Utilized: Body Mass Index $\geq 30 \mathrm{~kg} / \mathrm{m}^{2}$. ${ }^{* *} \mathrm{Imputed}$ Data. ${ }^{\star}$ Obtained by linear regression models and statistically significant for all cities and strata, except for Belém and the Federal District. 
Multilevel analysis on the prevalence of obesity in the country have described the spread of obesogenic environments in all capitals ${ }^{16}$, becoming indispensable the development of public policies and local actions towards the confronting of this epidemic.

In this sense, Brazil launched in 2011 the Brazilian Strategic Action Plan to Combat Chronic Non-Communicable Diseases (Plano de Ações Estratégicas para o Enfrentamento das Doenças Crônicas Não Transmissíveis) $2011-2022^{17,18}$, besides also having ongoing initiatives which include a national intersectoral plan for the prevention and control of obesity. These initiatives involve actions and policies of food and nutrition education, including the revision of the Food Guide for the Brazilian Population (Guia Alimentar para a População Brasileira), the Programa Saúde na Escola, intersectoral public policies in the field of food and nutrition security, promotion and supply of healthy foods in school settings, structuring actions of nutrition in primary care in the Sistema Único de Saúde, promotion of physical activity in the community, creating the Programa Academia da Saúde ${ }^{19}$ and regulatory and food control actions. These actions and policies seek to provide an intersectoral response able to halt and even reverse the epidemic rise of overweight and obesity in the country ${ }^{20}$.

The use of self-reported measures may be seen as a limitation of the study. However, several studies attest to the validity of this strategy ${ }^{21,22}$. Additionally, although the methodology for data collection may influence the absolute values of the estimated prevalence for each of the years, it should not influence the observed trends over time, since any effects of under or overestimation of prevalence will be constant over time.

Another limitation of this study is inherent to the methodology used by VIGITEL, which interviews only individuals living in households that have a landline. This problem, as was seen, is minimized by the use of weighting factors which equalized, each year, the sociodemographic characteristics of the sample studied by the VIGITEL to the characteristics of the total population of adults residing in the 27 cities monitored by the system ${ }^{11,12}$.

From 2012, the VIGITEL started using another method of post stratification (rake) ${ }^{12}$ and new population estimates from the 2010 Census. So then, the prevalence estimated here of overweight and obesity differ from the previously published data reports from VIGITEL, between 2006 and 2011, but are in accordance with the estimates of 2012's ${ }^{11}$. The weight and height data were imputed only in 2012, but showed little variation from the original data and did not change the trend.

\section{CONCLUSION}

The study points to the great problem of the increasing of overweight and obesity in Brazil. The intensity of the increase, of more than one percentage point per year in the case of overweight and almost one percentage point in the case of obesity, indicates that, maintaining this trend, in another ten years, about two-thirds of Brazilians living in those cities will be overweight and about a quarter will be obese. 
Therefore, the challenges to stop the growth of obesity and overweight are great, with goals set by the Plano de Ações Estratégicas para o Enfrentamento das Doenças Crônicas Não Transmissiveis in Brazil ${ }^{18}$. This effort requires a joint and integrated action of the different sectors of society as well as its active participation ${ }^{20}$.

\section{REFERENCES}

1. Organização Mundial de Saúde. Global status report on noncommunicable diseases 2010. Geneva: WHO; 2011.

2. Organização Mundial de Saúde. Diet, Nutrition and the Prevention of Chronic Diseases. Report FAO/ WHO Expert Consultation. WHO Technical Report Series, No. 916 (TRS 916). Geneva: WHO; 2003.

3. Organização Mundial de Saúde. WHO global strategy on diet, physical activity and health. Food Nutr Bull 2004; 25(3): 292-302.

4. Obesity: preventing and managing the global epidemic. Report of a who Consultation. World Health Organ Tech Rep Ser 2000; 894:i-xii, 1-253.

5. International Association for the Study of Obesity. Adult overweight and obesity in the European Union (EU27). London: IASO; 2012. Disponível em: http://www. iaso.org/resources/world-map-obesity/ (Acessado em novembro de 2013).

6. Ravussin E, Smith SR. Increased fat intake, impaired fat oxidation, and failure of fat cell proliferation result in ectopic fat storage, insulin resistance, and type 2 diabetes mellitus. Ann N Y Acad Sci 2002; 967: 363-78.

7. Moura EC, Claro RM. Estimates of obesity trends in Brazil, 2006-2009. Int J Public Health 2012; 57(1): 127-33

8. Ogden CL, Yanovski SZ, Carroll MD, Flegal KM. The epidemiology of obesity. Gastroenterology 2007; 132(6): 2087-102.

9. Schokker DF, Visscher TL, Nooyens AC, van Baak MA, Seidell JC. Prevalence of overweight and obesity in the Netherlands. Obes Rev 2007; 8(2): 101-8.

10. Brasil. Instituto Brasileiro de Geografia e Estatística. Pesquisa de orçamentos familiares 2008-2009: antropometria e estado nutricional de crianças, adolescentes e adultos no Brasil. Rio de Janeiro: IBGE; 2010.

11. Brasil. Ministério da Saúde. Secretaria de Vigilância em Saúde. VIGITEL. Brasil 2012: Vigilância de fatores de risco e proteção para doenças crônicas por inquérito telefônico. Brasília: Ministério da Saúde, 2013.

12. Izrael D, Hoaglin DC, Battaglia MP. A SAS macro for balancing a weighted sample. Proceedings of the twenty-fifth annual SAS users group International Conference, Paper 275; 2000.

13. Latorre MRDO, Cardoso MRA. Análise de séries temporais em epidemiologia: uma introdução sobre os aspectos metodológicos. Rev Bras Epidemiol 2001; 4(3): 145-52

14. Stata Corporation. Stata Statistical Software: Release 12.1 [computer program]. College Station: Stata Corporation.

15. Monteiro CA, Conde WL. A evolução da altura e do índice de massa corporal de crianças, adolescentes e adultos brasileiros, no período de 1974 a 2007. In: Saude Brasil. Brasília: Ministério da Saúde; 2009. p. 267-80.

16. Sichieri R, Moura EC. Análise multinível das variações no índice de massa corporal entre adultos, Brasil, 2006. Rev Saúde Pública 2009; 43(Supl 2): 90-7.

17. Malta DC, Morais Neto OL, Silva Júnior JB. Apresentação do plano de ações estratégicas para o enfrentamento das doenças crônicas não transmissíveis no Brasil, 2011 a 2022. Epidemiol Serv Saúde 2001; 20(4):425-38.

18. Brasil. Ministério da Saúde. Plano de ações estratégicas para o enfrentamento das doenças crônicas não transmissíveis (DCNT) no Brasil, 2011-2022. Brasília: Ministério da Saúde; 2011.

19. Malta DC, Silva Júnior JB. Policies to promote physical activity in Brazil. Lancet 2012; 380(9838): 195-6.

20. Jaime PC, Silva AC, Gentil PC, Claro RM, Monteiro CA. Brazilian obesity prevention and control initiatives. Obes Rev 2013; 14(2): 88-95.

21. Connor Gorber S, Tremblay M, Moher D, Gorber B. A comparison of direct vs. self-report measures for assessing height, weight and body mass index: a systematic review. Obes Rev 2007; 8(4): 307-26.

22. Peixoto MR, Benício MH, Jardim PC. Validade do peso e altura referidos: o estudo de Goiânia. Rev Saúde Pública 2006; 40(6): 1065-72.

Received on: 01/14/2014

Final version presented on: 04/08/2014

Accepted on: 05/09/2014 